\title{
Dual Effect Exhibited by Insulin in Myeloma and Lymphoblastoid Cells
}

\author{
Sain S. Shushanov 1,*(D), Anastasiia A. Kalinina ${ }^{1(\mathbb{D})}$, Tatiana A. Kravtsova ${ }^{1(\mathbb{D})}$ \\ Alexander M. Sherbakov ${ }^{1}$ (D), Yliya B. Chernykh ${ }^{2}$ (D), Natalia P. Akentieva ${ }^{3}$ (D) \\ 1 FSBI «N.N. Blokhin NMRCO» of the Ministry of Health of the Russian Federation, 115522, Kashirskoe shosse, 24, \\ Moscow, Russia \\ 2 Moscow Regional Research and Clinical Institute of M.F. Vladimirsky (MONIKI), 61 Shchepkin street/2k11, Moscow, \\ Russia \\ 3 Institute of Problems of Chemical Physics Russian Academy of Sciences, 142432 Moscow Region, Academician Semenov \\ Avenue, 1, City Chernogolovka, Russia \\ * Correspondence: sainHershy@yandex.ru (S.S.S.);
}

Scopus Author ID 8760213400

Received: 21.05.2021; Revised: 25.06.2021; Accepted: 1.07.2021; Published: 8.08.2021

\begin{abstract}
Many reports have documented the role of INS (insulin) as growth factors in a variety of cancers. Epidemiological studies revealed that INS therapy causes increased mortality in multiple myeloma (MM) patients with pre-existing or steroid-induced type 2 diabetes. However, there is limited experimental evidence of this association. In the present study, the dual effect of INS on the viability of myeloma RPMI8226 and lymphoblastoid IM9 cells was revealed. In serum-containing medium exogenous INS serves as a growth factor, whereas INS decreases the number of cells under serum-free medium. In the last case, the main mechanism of decreasing the cell population is apoptosis through up-regulation of Cas-3 and downregulation of $\mathrm{Bcl}-2$ expression. INS has also been shown to be involved in the regulation of necrotic cell death.
\end{abstract}

Keywords: multiple myeloma (MM); insulin (INS); apoptosis; gene expression; cancer.

(C) 2021 by the authors. This article is an open-access article distributed under the terms and conditions of the Creative Commons Attribution (CC BY) license (https://creativecommons.org/licenses/by/4.0/).

\section{Introduction}

Epidemiological studies have shown that chronic insulin resistance is a potential risk factor for endometrial cancer [1], breast cancer [2], colorectal cancer [3], and several other malignancies [4-7]. In addition, there is also evidence that in patients with type 2 diabetes (T2DM), hypoglycemic therapy using INS and sulfonylureas, as well as INS analogs, increases the risk of malignancy $[8,9]$. At the present time, the reasons for the relationship between INS resistance and increased risk of malignancy have not been established. Earlier it has been shown that the expression of INS receptors is not limited to classical insulin target tissues, such as the liver, adipose tissue, skeletal muscle, and brain; they are also detected in the heart, lungs, pancreas, kidneys, and other tissues [4-6]. In this regard, it is assumed that in the case of obesity or T2DM, some of these tissues may remain sensitive to insulin. Besides this, in conditions of chronic hyperinsulinemia, INS-dependent signals are constitutively stimulated in them, leading to various pathologies, including malignant cell transformation, and the worst-case scenario develops when cancer cells in a T2DM patient overexpress the INS receptor and show a pronounced sensitivity to INS [4-6]. 
Multiple myeloma (MM) is a clonal B-cell malignancy in which monoclonal plasma cells proliferate in bone marrow, resulting in an overabundance of monoclonal paraprotein $(\mathrm{M}$ protein), anemia, hypercalcemia, renal insufficiency, osteolytic bone lesions, and decreased immune function. $\mathrm{MM}$ is the second-most common hematologic malignancy. Although the drug store has grown significantly in the last few years, there are no definitive curative actions for MM, so it is particularly important to develop new chemotherapeutic agents with new mechanisms of action [10-14]. Among these works, there is also our research recently published in this journal [15]. The involvement of paraproteins produced by malignant plasma cells in the development of hyperlipidemia and low-HDL cholesterol has been described, as has an association with MM and obesity, and T2DM, and INS resistance, that is, features of the metabolic syndrome (MS) [16]. A retrospective case review of 82 patients at various stages of their MM disease pathway reported that $58.5 \%$ of patients had one or more features consistent with MS, including some with T2DM [17]. And what is significant, diabetes is associated with a higher risk of hematological malignancies, including multiple myeloma [18].

There is epidemiological evidence that insulin therapy causes increased mortality in MM patients with pre-existing or steroid-induced T2DM. It was shown that the median overall survival of MM patients with diabetes was 65.4 months compared to 98.7 months among MM patients without diabetes [19]. At least one fundamental study established that INS is a potent growth factor for myeloma cells [20]. Also was shown that functional insulin receptors are preferentially expressed in multiple myeloma cell lines compared to B-lymphoblastoid cell lines [21]. Earlier, we have shown that INS affects the survival of human MM cells [22]. Our current work established that INS has a dual impact on MM cells: INS is really a growth factor for MM cells, but on the other hand, it is an inducer of cell death.

\section{Materials and Methods}

\subsection{Materials.}

We used the growth medium RPMI1640 (25 mM HEPES, sodium pyruvate, OOO NPP PanEco, Catalog \#C350p, Russia), Fetal Bovine Serum (FBS, Biosera, Catalog \# FB-1001/500, South America Origin), L-glutamine (OOO NPP PanEco, Catalog \# FO32, Russia), Gentamicin (10 mg/ml, OOO NPP PanEco, Catalog \# A011, Russia). Plastic dishes (culture flasks $25 \mathrm{~cm}^{2}$, disposable pipettes) and 24-wells plates for growing the cell culture were purchased from Corning-Costar, (USA). Human INS was purchased from Sigma-Aldrich (Catalog \# 19278-5ML, USA).

\subsection{Cell lines.}

Two completely different types of cell lines were used: established human myeloma cell line (HMCL) RPMI8226 (CD138+, CD38+, CD45-, CD56 , CD19-), which express the differentiation markers indicated in parentheses on their surface, and lymphoblastoid cell line (LCL) IM9 (CD138+, CD38-, CD45+, CD56-, CD19+), which result from the immortalization of nonmalignant $\mathrm{B}$ cells by Epstein-Barr virus (EBV) [23, 24]. Cells cultured in growth medium RPMI with $10 \% \mathrm{FBS}$ at $37^{\circ}, 5 \% \mathrm{CO}_{2}$, and $95 \%$ humidity. The cells were grown to $90 \%$ density in culture flasks. 


\subsection{Colorimetric MTT assay.}

The compound MTT was adopted to assess cell proliferation. Briefly, RPMI8226 and IM9 cells were seeded into 96-well plates at a density of $20 \times 10^{3}$ cells per well in triplicate in $150 \mu \mathrm{l}$ of serum-free medium without INS (control) or with INS at a concentration of $0.1 \mathrm{U} / \mathrm{ml}$. These conditions were repeated for containing a growth medium. After incubation for $72 \mathrm{~h}, 20$ $\mu 15 \mathrm{mg} / \mathrm{ml} \mathrm{MTT}$ was added to each well, and the cells were incubated at $37^{\circ} \mathrm{C}$ for another $4 \mathrm{~h}$. Subsequently, the media was discarded, followed by the addition of $150 \mu 1$ DMSO per well to dissolve the purple precipitate. The absorbance (A) was measured at $570 \mathrm{~nm}$ using a microplate reader. The cell growth $(\%)$ was calculated according to the following equation: $\%$ viable cells $=\left(A_{\text {sample }}-\right.$ Ablank $) /\left(\right.$ Acontrol $\left._{\text {- Ablank }}\right) \times 100 \%$, where Acontrol is the absorbance of the untreated cells, Asample is the absorbance of the cells exposed to INS and Ablank is the absorbance of the media.

\subsection{Study of apoptosis by flow cytometry.}

Cells were seeded in a 24-wells plate of $3 \times 10^{5}$ cells per well in $1 \mathrm{ml}$ of serum-free growth medium without INS (control) or, in serum-free medium, but containing human INS (Sigma, Catalog \# 19278-5ML) at a concentration of: 0.0 (control); $10^{-4}, 10^{-3}, 10^{-2}, 10^{-1}, 1.0$, or $3.0 \mathrm{U} / \mathrm{ml}$. These conditions were repeated for a serum-containing growth medium. The cells were incubated for $72 \mathrm{~h}$ in an atmosphere with $5 \% \mathrm{CO}_{2}$. After $72 \mathrm{~h}$ the measurement was performed on a flow cytometer. Apoptosis was studied using the Annexin V-FITC Kit (Sigma, USA). The measurement procedure was performed according to the next protocol. Briefly, cells were deposited by centrifugation at $300 \mathrm{x}$ g for 5-10 $\mathrm{min}$ at room temperature. The cell precipitate was resuspended in $500 \mu \mathrm{l}$ of cold $\left(4^{0} \mathrm{C}\right) 1 \mathrm{X}$ PBS buffer and again precipitated by centrifugation. The cell precipitate was gently resuspended in an Annexin V incubation reagent (10 $\mu 1$ of 10X binding buffer, $10 \mu 1$ of propidium iodide, $1 \mu \mathrm{l}$ of Annexin V-FITC and $79 \mu 1$ of distilled $\mathrm{H}_{2} \mathrm{O}$ ) prepared at the rate of $100 \mu \mathrm{l}$ per $10^{5}-10^{6}$ cells. Resuspended cells were incubated in darkness for $15 \mathrm{~min}$ at room temperature. Then $400 \mu \mathrm{l}$ of binding buffer was added and measured using a flow cytometer (BD FACSCantoTM II Flow Cytometer).

\subsection{RNA extraction, reverse transcription and $q R T-P C R$.}

After $72 \mathrm{~h}$ of the cells exposed to INS, total RNA was extracted by a single-step technique using TRI Reagent (Sigma, USA) according to the manufacturer's protocol. For cDNA synthesis, $2 \mu \mathrm{g}$ of total RNA was reverse-transcribed using oligo dT18 primers and MMLV RT enzyme. Quantitative polymerase chain reaction (qRT-PCR) was performed on a CFX 96 Touch Real-Time PCR (Bio-Rad, USA), using SYBR Green reporter fluorescent dye according to the manufacturer's protocol. The cycling conditions were as follows: $95^{\circ} \mathrm{C}$ for 5 minutes and 40 cycles of $95^{\circ} \mathrm{C}$ for 15 seconds followed by $60^{\circ} \mathrm{C}$ for 25 seconds and $72^{\circ} \mathrm{C}$ for 25 seconds. All values were normalized to actin expression. Primer sequences were as follows: Cas-3 5'-ACATGGCGTGTCATAAAATACC - 3' (forward), and 5'CACAAAGCGACTGGA TGAAC - 3' (reverse); Bcl-2 5' - TTGGCCCCCGTTGCTT - 3' (forward) and 5'- CGGTTATCGTACCCTGTTCTC -3' (reverse); Actin 5'AGCCATGTACGTTGCTATCCA - 3' (forward) and 5'- ACCGGAGTCCATCACGATG 3'(reverse). Under these conditions, no amplification was observed in the non-template or no RT controls. The specificity of the amplification product was determined by melting curve 
analysis for each primer pairs. The data were analyzed by the comparative CT method and the fold change was calculated by the $2-\Delta \Delta \mathrm{CT}$ method.

\subsection{Statistical analysis.}

Statistical analysis of the obtained data was performed using the computer program GraphPad Prizm 5.02 (GraphPad Software Inc., USA). Statistical differences for flow cytometer analyses were determined using one-way ANOVA followed by Tukey's Multiple Comparison Test between experimental groups. Statistical differences for qRT-PCR and colorimetric MTT analyses were determined using Student t-test for two-group comparisons. All cell experiments were performed in three or more independent repeats. Data are expressed as means \pm standard error of the mean $(\mathrm{SEM})$. $\mathrm{P}$ values $<0.05$ were used to represent significance.

\section{Results and Discussion}

\subsection{Effects of INS on the proliferation of RPMI8226 and IM9 cells.}

MTT assay demonstrated that the INS enhances FBS induced proliferation of RPMI8226 and IM9 cells (Figure 1A and Figure 1B), and intensifies the growth suppression effect in the medium without FBS (Figure 1C and Figure 1D).

The concentration of INS required for stimulating cell growth in vitro in almost all cases is extraordinarily high compared with physiological concentration [25 - 31].

RPMIS226

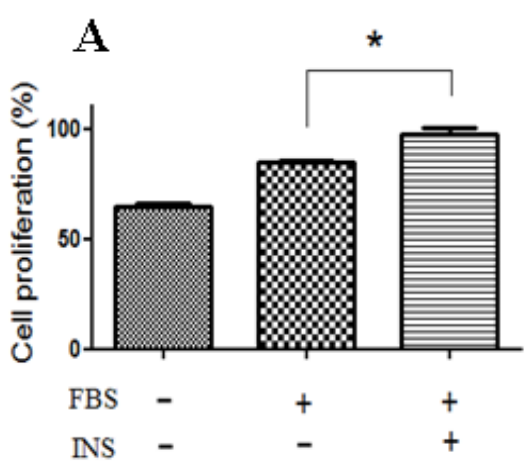

RPMIS226

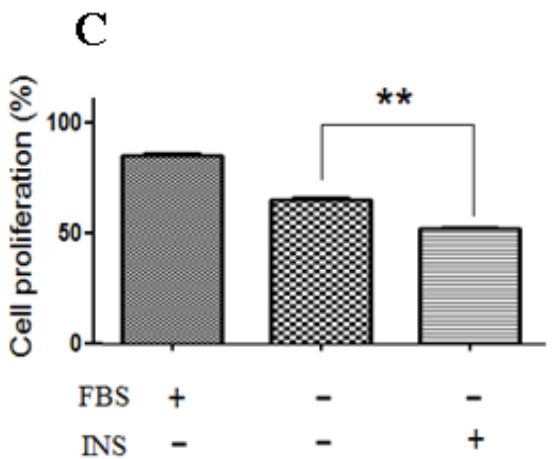

IM9

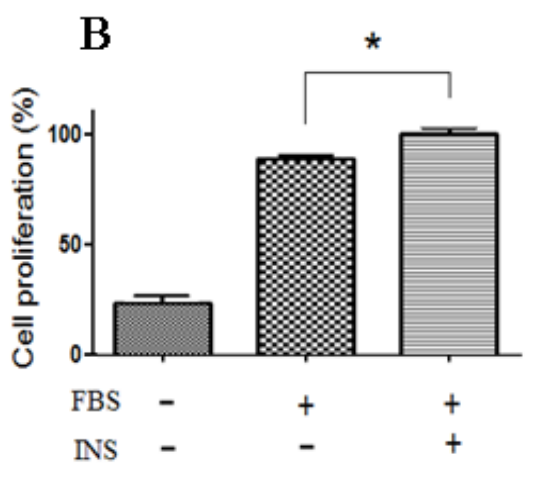

IM9

D

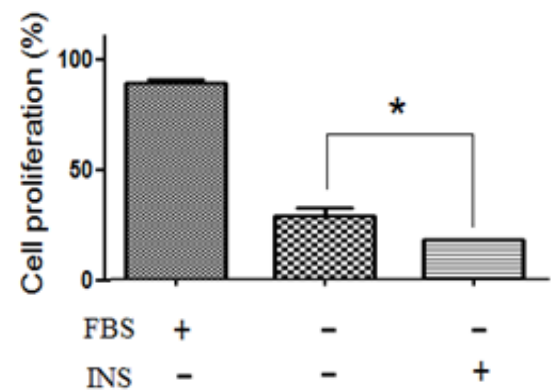

Figure 1. Effects of INS on the proliferation of RPMI8226 and IM9 cells. 
In this experiment, we used INS in concentration $10^{-1} \mathrm{U} / \mathrm{ml}$, which is corresponded to the concentration range recommended by the product specification sheet for cell culture applications (INS, Sigma-Aldrich, Catalog \# 19278-5ML, USA). To verify whether serum is important for INS-dependent cell growth, we administered to growth medium various serum concentrations $(0 \%, 0.1 \%, 1 \%$, and $10 \%)$ for $72 \mathrm{~h}$. The results demonstrated that indeed INS downregulates cell growth at the full absence of FBS, and positively cooperates with FBS by reaching maximum growth effect at the $10 \%$ of FBS (Figure 2A and Figure 2B). Notably, the INS-dependent cell growth effect became significant when the cells were grown at $10 \%$ of FBS. Thus we can conclude that in serum-containing medium INS really serves as a growth factor, but without serum, it may block cell growth or induce cell death.

(1A, 1B) - INS enhances FBS-induced proliferation of RPMI8226 and IM9 cells. (1C, 1D) - INS intensifies the growth suppression effect in the absence of FBS. MTT assay, the cells were treated with INS in concentration $10^{-1} \mathrm{U} / \mathrm{ml}$ for $72 \mathrm{~h}$. Data are presented as the mean \pm standard deviation ( $\mathrm{n}=3)$. $* \mathrm{P}<0.05$ vs. control group; INS (insulin); FBS (fetal bovine serum).

RPMI8226

A

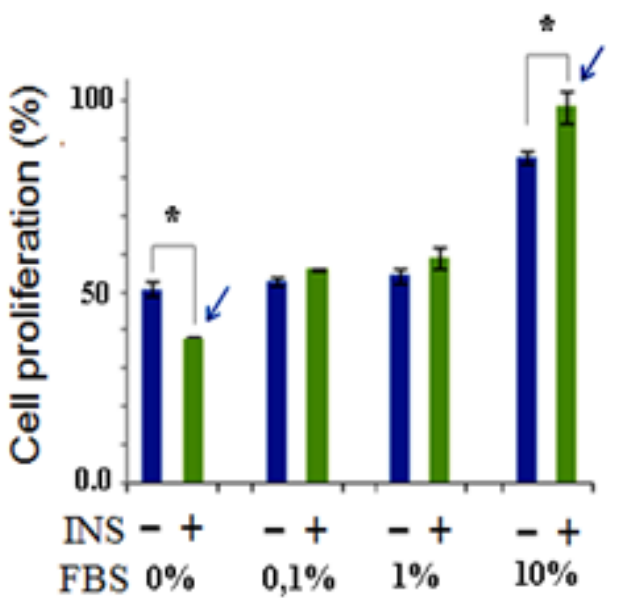

IM9

B

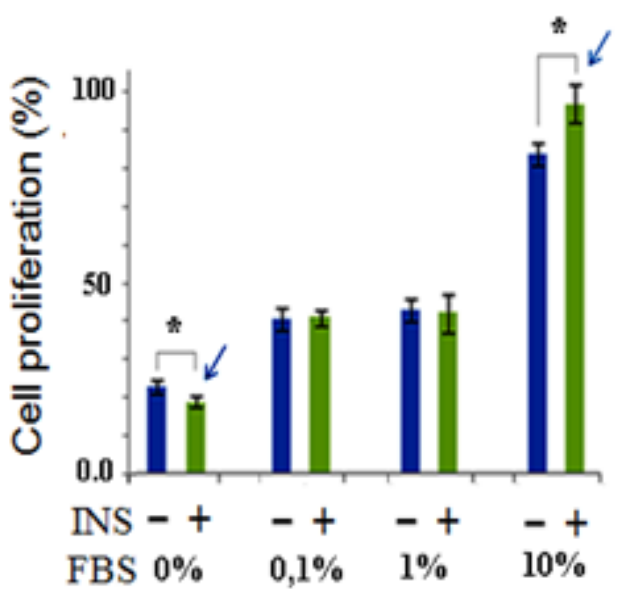

Figure 2. INS enhances FBS-induced proliferation of RPMI8226 and IM9 cells.

INS positively cooperates with FBS by reaching maximum cell growth effect at $10 \%$ of FBS. MTT assay, the RPMI8226 (2A) and IM9 (2B) cells were growth in concentrations of serum $(0 \%, 0.1 \%, 1 \%$ and $10 \%)$ in the presence or absence of INS in concentration $10^{-1} \mathrm{U} / \mathrm{ml}$ for $72 \mathrm{~h}$. Data are presented as the mean \pm standard deviation $(\mathrm{n}=3)$. $* \mathrm{P}<0.05$ vs. control group; INS (insulin); FBS (fetal bovine serum).

\subsection{INS intensifies apoptosis induced by serum starvation.}

To determine the mechanism by which INS heightens cell death in a medium without serum, we investigated the possible impact of INS on apoptosis. For this purpose, RPMI8226 and IM9 cells were seeded in a 24-wells plate of $3 \times 10^{5}$ cells per well in $1 \mathrm{ml}$ of serum-free growth medium containing human INS at a concentration of: 0.0 (control); $10^{-4}, 10^{-3}, 10^{-2}, 10^{-}$ 1 , 1.0, or $3.0 \mathrm{U} / \mathrm{ml}$. These conditions were repeated for a $10 \%$ serum-containing growth medium. The measurement of apoptosis was performed on a flow cytometer using the Annexin V-FITC. As presented in Figure 3A and Figure 3C INS intensifies apoptosis induced by serum starvation as for RPMI8226 and for IM9 cells, and the apoptotic extent are increased by dose depending manner. The indicated concentrations of INS in the culture medium with $10 \%$ FBS 
do not induce any apoptosis of either RPMI8226 cells or IM9 cells, even at a concentration of INS 3.0 U/ml (Figure 3B and Figure 3D). Our experiments were also performed at $48 \mathrm{~h}$, and the results were similar but not as pronounced as at $72 \mathrm{~h}$. Thus our data allow approving that INS can hike cell apoptosis induced by serum starvation.

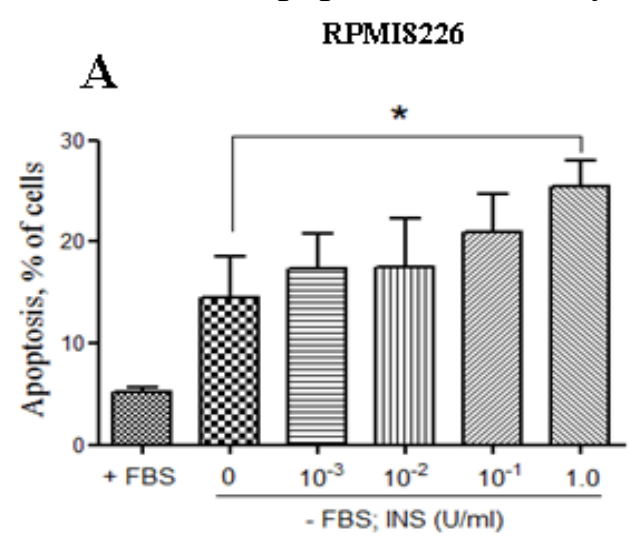

\section{B}

RPMIS226

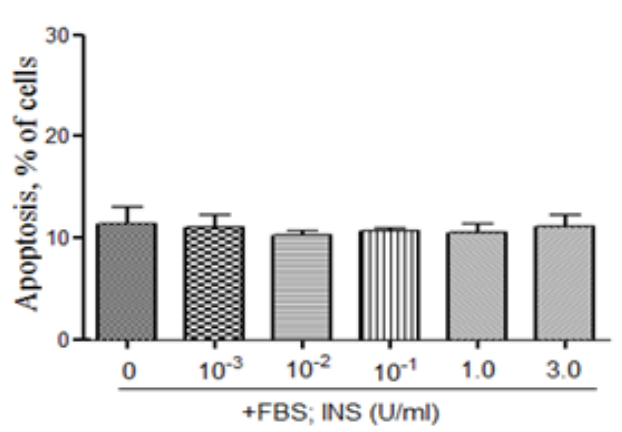

IM9

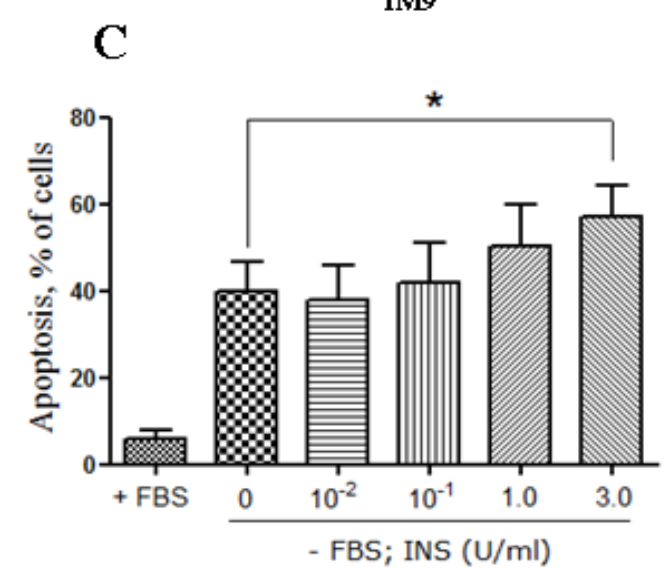

D

IM9

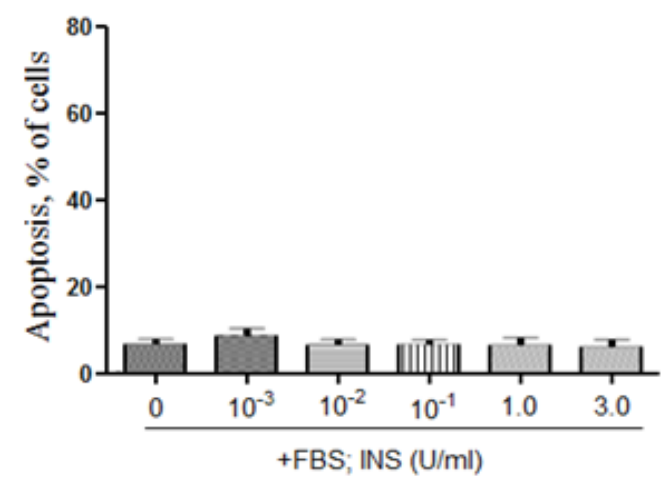

Figure 3. INS intensifies apoptosis induced by serum starvation. Flow cytometry analysis, RPMI8226 (4A, 4B) and IM9 (4C, 4D) cells were seeded in a 24-wells plate of $3 \times 10^{5}$ cells per well in GM with or without $10 \%$ FBS, at presence various concentrations of INS: 0.0 (control); $10^{-4}, 10^{-3}, 10^{-2}, 10^{-1}, 1.0$, or $3.0 \mathrm{U} / \mathrm{ml}$ for $72 \mathrm{~h}$. Data are presented as the mean \pm standard deviation $(\mathrm{n}=3)$. $* \mathrm{P}<0.05$ vs. control group; INS (insulin); FBS (fetal bovine serum); GM (growth medium).

\subsection{INS intensifies a diminishing of cell number induced by serum starvation.}

Flow cytometry allowed at the same time to estimate the number of living cells. As presented in Figure 4A and Figure 4C INS intensifies a diminishing of living cell number induced by serum starvation and acts by dose depending manner. This data proves our data obtained by MTT assay and shows that INS indeed downregulates cell proliferation without FBS. Also, it allows observation that decreasing of living cell number strictly correspond to rise of INS depending on apoptosis. The indicated concentrations of INS in the presence of $10 \%$ FBS do not affect the change in the number of RPMI8226 or IM9 cells (Figure 4B and Figure 4D). 


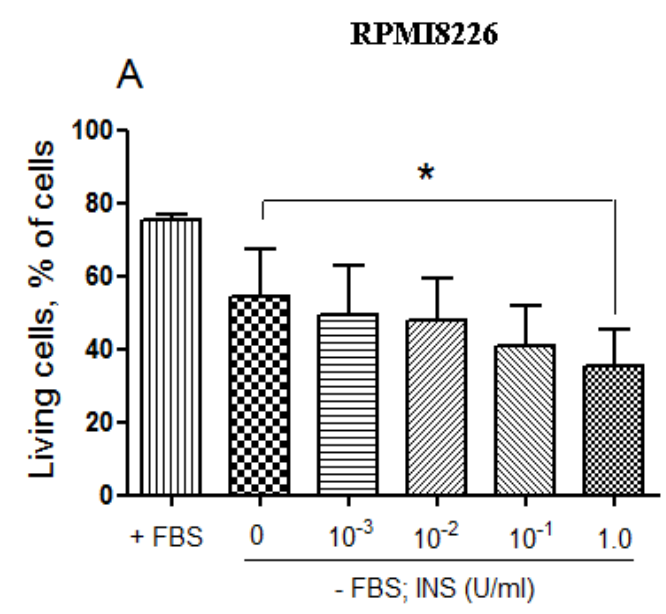

$\mathrm{C}$

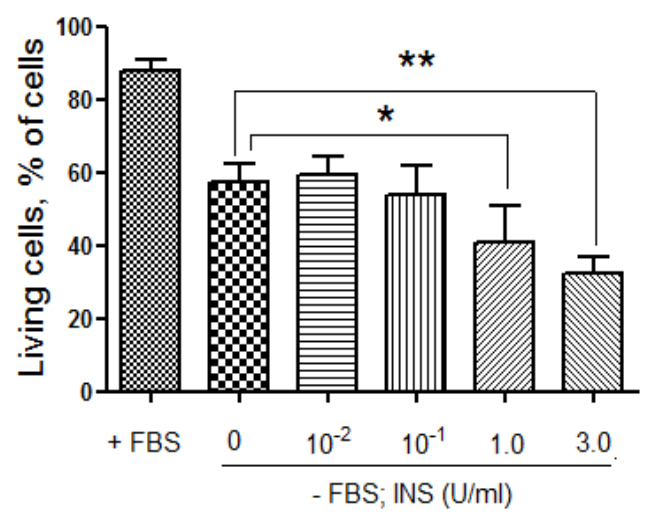

RPMI8226

B

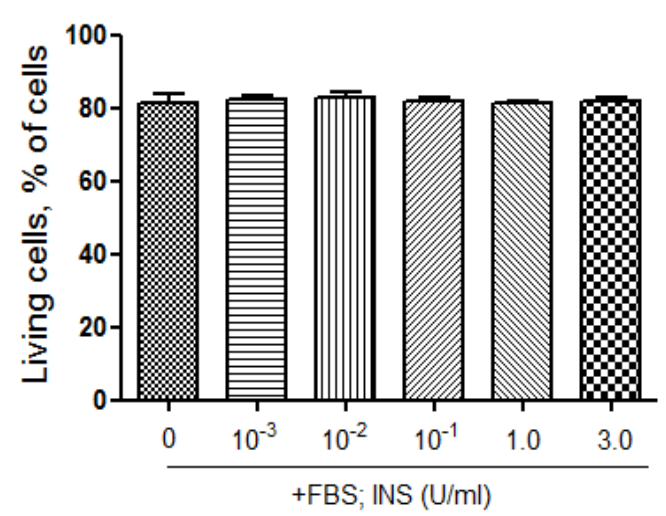

IM9

D

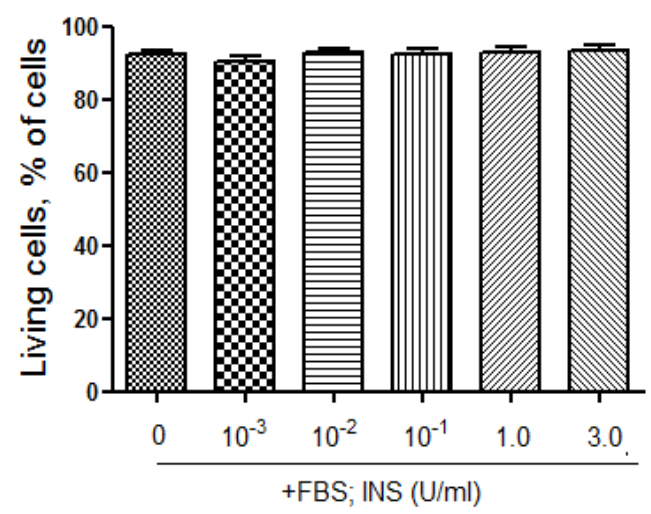

Figure 4. INS intensifies a decrease of living cell number induced by serum starvation. Flow cytometry analysis (4A, 4C).The decreasing living cell number strictly corresponds to the rise of INS depending on apoptosis (4B, 4D). Indicated concentrations of INS in the presence of $10 \%$ FBS do not downregulate a number of either RPMI 8226 cells or IM9 cells even at 3,0 U/ml of INS. Data are presented as the mean \pm standard deviation $(n=3)$. $* \mathrm{P}<0.05$ vs. control group; INS (insulin); FBS (fetal bovine serum).

\subsection{Necrosis in response to treatment with INS.}

We investigated the role of INS in regulating the necrosis of RPMI8226 and IM9 cells. The measurement of necrosis was performed on flow cytometry. As presented in Figure 5A and Figure 5C in the serum-free medium INS does not impact the necrosis for RPMI8226 cells. It intensifies the necrosis of IM9 cells induced by serum starvation. INS acts by dose depending manner and can hike necrosis depending on the context of the cells. In this case, RPMI8226 and IM9 cells differ in differentiation markers and origin: RPMI8226 are myeloma cells, and IM9 are lymphoblastoid cells, which are more sensitive to serum. The indicated concentrations of INS in the culture medium with 10\% FBS do not cause necrosis of either RPMI8226 cells or IM9 cells (Figure 5B and Figure 5D). 
A

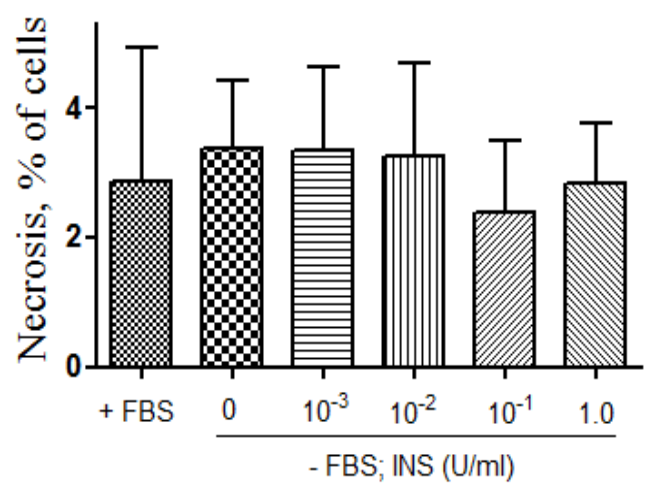

$\mathrm{C}$

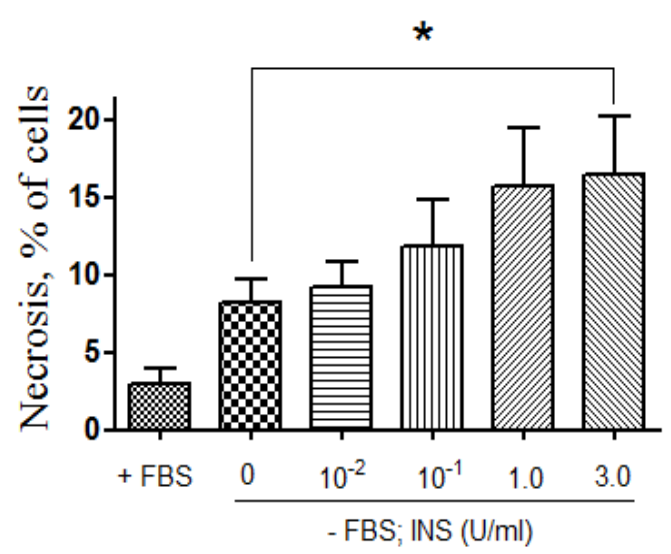

B

RPMI8226

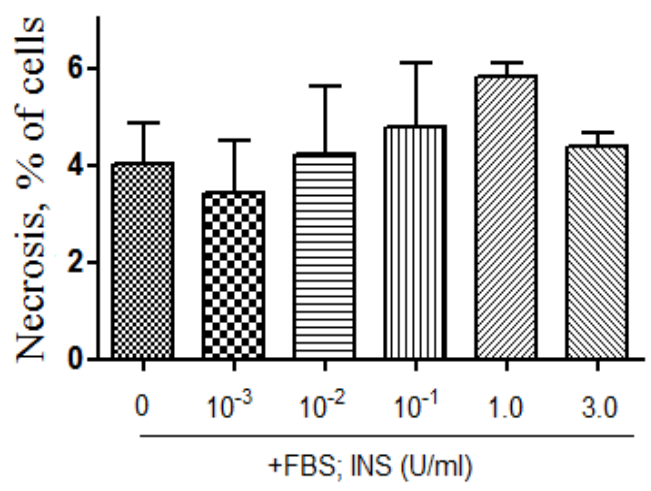

IM9

D

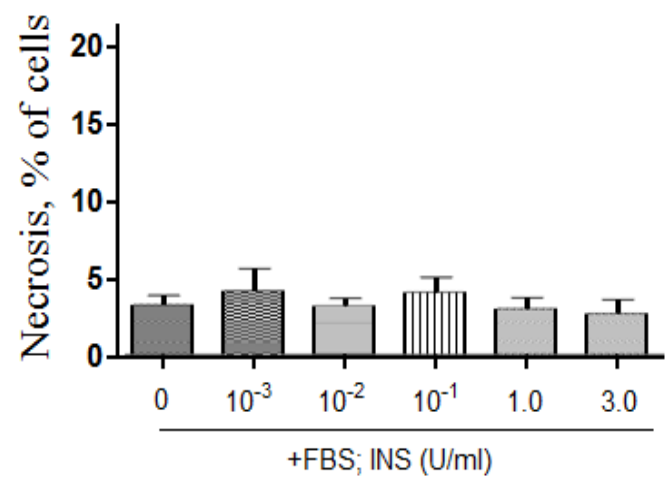

Figure 5. INS hikes necrosis induced by serum starvation depending on the context of the cells. Flow cytometry analysis: INS does not impact the necrosis for RPMI8226 cells (5A) and intensifies the necrosis of IM9 cell (5C) induced by serum starvation. Indicated concentrations of INS in the presence of $10 \%$ FBS do not affect the number of either RPMI 8226 cells or IM9 cells. Data are presented as the mean \pm standard deviation $(n=3)$. $* \mathrm{P}<0.05$ vs. control group; INS (insulin); FBS (fetal bovine serum).

\subsection{Effects of INS on the Cas-3 and Bcl-2 mRNA expression levels.}

Cas-3 and Bcl-2 genes play an important role in regulating cell survival and cellular apoptosis. The RPMI8226 and IM9 cells were seeded in a 12-wells plate of $6 \times 10^{5}$ cells per well in $2 \mathrm{ml}$ of serum-free growth medium containing human INS at a concentration of: 0.0 (control) and $10^{-1} \mathrm{U} / \mathrm{ml}$ for $72 \mathrm{~h}$. These conditions were repeated for a $10 \%$ serum-containing growth medium. Then mRNA expression level in response to treatment with INS was measured by RT qPCR. The used concentration of INS has corresponded to the concentration range recommended by the product specification sheet for cell culture applications (INS, SigmaAldrich, Catalog \# 19278-5ML, USA). The results indicated that in serum-free medium, INS up-regulated the pro-apoptotic Cas-3 gene mRNA levels in both RPMI8226 cells (Figure 6A) and IM9 cells (Figure 6B). And the same time INS down-regulated anti-apoptotic Bcl-2 gene mRNA expression levels in both RPMI8226 cells (Figure 6C) and IM9 cells (Figure 6D). In the presence of $10 \%$, FBS INS treatment did not affect amounts of Cas-3 and Bcl-2 mRNA 
(data not shown). Thus we can conclude that apoptosis in RPMI8226 and IM9 cells in response to treatment with INS can regulate by Cas-3 and Bcl-2 genes.
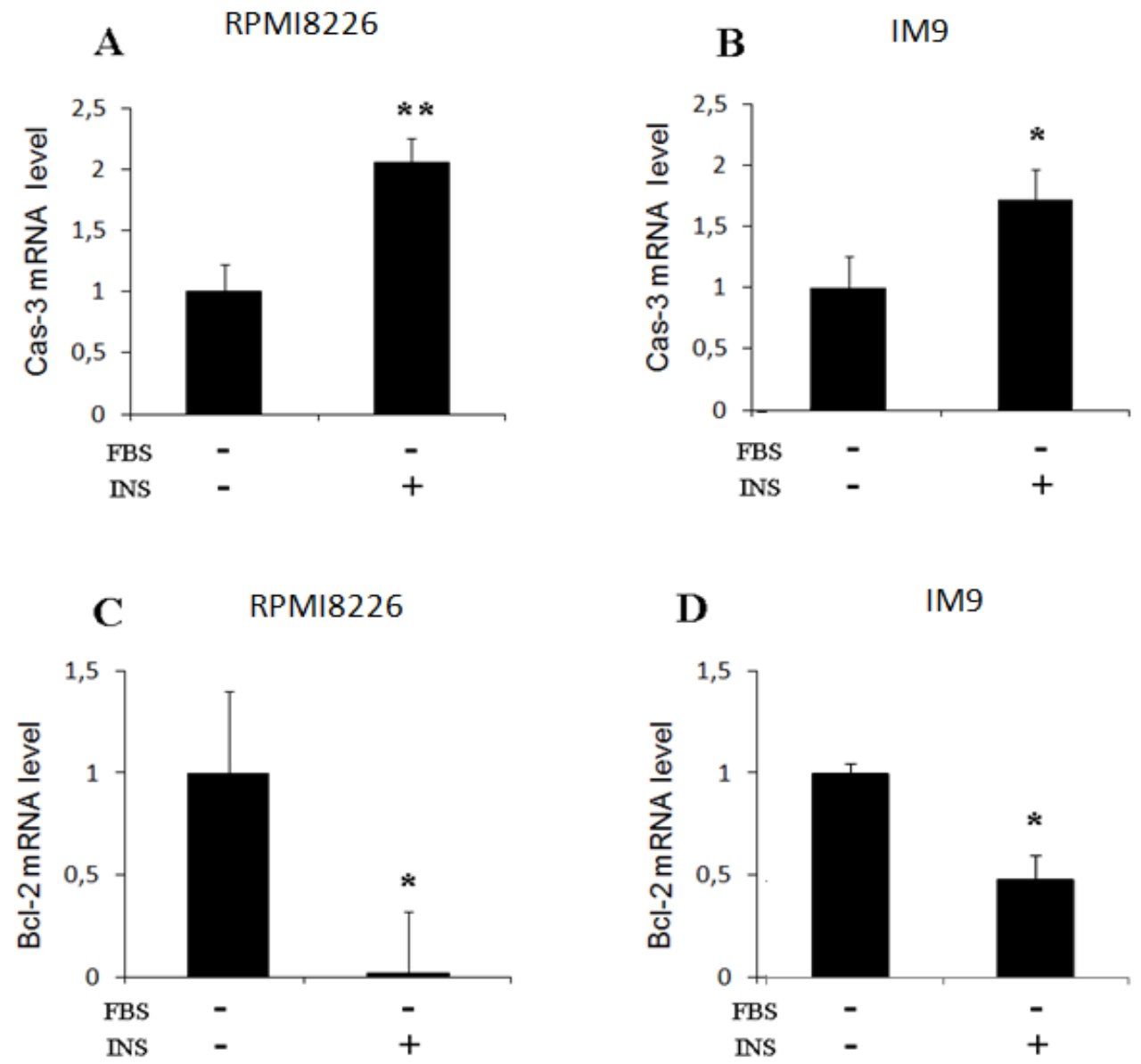

Figure 6. Cas-3 and $B c l-2$ mRNA expression level in response to treatment with INS. In serum-free medium INS up-regulated Cas-3 mRNA expression levels in both RPMI8226 (6A) and IM9 (6B) cells; and same time INS down-regulated Bcl-2 mRNA expression levels in both RPMI8226 cells (6C) and IM9 cells (6D). The mRNA level was measured by RT-qPCR. The cells were treated with INS in concentration $10^{-1} \mathrm{U} / \mathrm{ml}$ for $72 \mathrm{~h}$. Data are presented as the mean \pm standard deviation $(n=3)$. $* \mathrm{P}<0.05$ vs. control group; INS (insulin); FBS (fetal bovine serum); RT-qPCR, (quantitative polymerase chain reaction).

In the current study, the dual effect of INS on the viability of myeloma RPMI8226 and lymphoblastoid IM9 cells were revealed. In a serum-containing medium, INS really serves as a potent growth factor, whereas serum-free medium INS at the same concentrations downregulated the growth of cells and intensifies apoptosis induced by serum starvation. The first observation of the growth-stimulatory effect of insulin in tissue culture was made by Gey and Thalhimer in 1924 [31]. Subsequently, insulin has been shown to stimulate the growth and proliferation of a variety of cells in culture; and some, but not all, of the effects of insulin on growth, require superphysiological concentrations of insulin [25-31]. There are a number of possible explanations for this observation [25].

INS is one of the key growth factors for many types of neoplastic cells [32-40], and it is a potent growth factor for myeloma cells [20]. Our data fully confirm these dates and show that INS enhances serum-induced proliferation of RPMI8226 and IM9 cells (Figure 2A and Figure 2B). According to earlier data, insulin receptors are preferentially expressed in multiple myeloma cell lines [21]. We conclude that activation of INS depending signaling is a poor prognostic factor for patients with MM. Thus our data may explain the epidemiological https://biointerfaceresearch.com/ 
evidence revealed by $\mathrm{Wu}$ et al. that INS therapy causes increased mortality in MM patients who had pre-existing or steroid-induced T2DM [19].

It is a well-known fact that INS can induce cell apoptosis. For example, chronic INS resistance is associated with a compensatory increase in beta-cell mass and increased INS secretion. Over time, under conditions of a constant high concentration of INS, beta-cells fail, are destroyed, and diabetes begins. The main mechanism of beta-cell death is INS-induced apoptosis [41]. Moreover, prolonged exposure to insulin inactivates Akt and Erk1/2 and increases apoptosis of pancreatic islets and INS1E b cells [42]. Furthermore, it has been established that INS dose-dependent activated proliferation and induced apoptosis of $\mathrm{C} 2 \mathrm{C} 12$ cells through regulation of cyclin D1 and BAD expression [43]. Insulin, in combination with cisplatin, induces the apoptosis of ovarian cancer cells [44]. In addition, it has also been shown that exposure to INS for 72 hours on primary rat embryonic adipocytes maintained in culture induces apoptosis [45]. Prolonged insulin treatment sensitizes apoptosis pathways in pancreatic $\beta$ cells [46]. Thus, these studies suggest that the long-term effect of INS on cells reflects the state of hyperinsulinemia in type 2 diabetes that causes cell apoptosis.

Our data demonstrated that INS intensifies apoptosis induced by serum starvation as for RPMI8226 and for IM9 cells, and the apoptotic extent is increased by INS dose depending manner. Apoptosis is accompanied by up-regulation of Cas-3 mRNA expression levels and down-regulation of Bcl-2 mRNA expression levels. There were demonstrated earlier that the caspase-3, Bcl-2, and his family members contribute significantly to the regulate apoptosis of human MM cells [47-52].

Our data demonstrated that INS enhances a diminishing of living cell number, which strictly corresponds to the rise of apoptosis. As well, INS effect on necrosis of cells depends on the context of the cells.

At that time, we demonstrate that INS in the presence of serum does not cause apoptosis, not of either RPMI8226 or IM9 cells, does not affect the change in their number, and does not cause necrotic death. One reason is that INS can manifest its functions in interaction with growth factors and cytokines contained in the serum. For example, it was shown that the proliferation of poultry intestinal crest cells requires the cooperation of insulin and glia-derived neurotrophic factor (GDNF) [53]. In addition, INS and GDNF alone can initiate DNA synthesis in these cells, but their combined combination is necessary for the longterm maintenance of proliferation. Another study showed that the proliferation of imaginal disk cells requires the cooperation of INS with the imaginal disk growth factor (IDGF) [54]. Besides this, it has also been shown that INS cooperates with IL-1 in rat hepatoma cells [55]. It was found that adipose tissue macrophages produce interleukin-10 (IL-10) upon feeding, which cooperates with INS, and their combination suppresses hepatic glucose production in [56].

The part of our experiments was carried out in a media without serum (without growth factors). Under such an environment, both myeloma and lymphoblastoid cells are weakened, and to some extent, they are similar to "weakened" (due to metabolic disorders) normal cells of patients with T2DM-associated chronic hyperglycemia, which are, possible, poorly respond to growth - and survival factors and insulin therapy of MM patients with T2DM are exposed them to apoptosis. It seems to be this is one of the reasons that insulin therapy causes increased mortality in MM patients who had pre-existing or steroid-induced T2DM [19]. Indeed it was revealed that prolonged high-glucose exposure leads to the blockage or change of the different cell signaling [57-61]. 


\section{Conclusions}

In summary, the results reported here allow us to conclude that activation of INS depending signaling is a poor prognostic factor for MM patients with T2DM. On the one hand, INS is a pronounced growth factor for myeloma cells, and on the other hand, it is possible that INS in some cases can negatively affect normal cells with significantly altered cellular signaling systems in patients with T2DM-associated chronic hyperglycemia.

\section{Funding}

This research was funded by the Ministry of Science and Higher Education of the Russian Federation and performed by the state task, state registration \# AAAA-A19-119071890015-6 and \# 2020-18.

\section{Acknowledgments}

This research has no acknowledgment.

\section{Conflicts of Interest}

The authors declare no conflict of interest. The funders had no role in the study's design, in the collection, analyses, or interpretation of data, in the writing of the manuscript, or in the decision to publish the results.

\section{References}

1. Mu, N.; Zhu, Y.; Wang, Y.; Zhang, H.; Xue, F. Insulin resistance: a significant risk factor of endometrial cancer. Gynecologic Oncology. 2012, 125, 751-757, https://doi.org/10.1016/j.ygyno.2012.03.032.

2. Larsson, S.C.; Mantzoros, C.S.; Wolk, A. Diabetes mellitus and risk of breast cancer: a meta-analysis. Int J Cancer. 2007, 121, 856-862. https://doi.org/10.1002/ijc.22717.

3. Lu, C.C.; Chu, P.Y.; Hsia, S.M.; Wu, C.H.; Tung, Y.T.; and Yen, G.C. Insulin induction instigates cell proliferation and metastasis in human colorectal cancer cells. Int $J$ Ocology. 2017, 50, 736-744, https://doi.org/10.3892/ijo.2017.3844.

4. Arcidiacono, B.; Iiritano, S.; Nocera. A.; Possidente, K., Nevolo, M.T.; Ventura, V.; Foti, D.; Chiefari, E.; Brunetti, A. Insulin Resistance and Cancer Risk: An Overview of the Pathogenetic Mechanisms. J. Diabetes Res. 2012, 789174, https://doi.org/10.1155/2012/789174.

5. Giovannucci, E.; Harlan, D.M.; Archer, M.C.; Bergenstal, R.M.; Gapstur, S.M.; Habel, L.A.; Pollak, M.; Regensteiner, J.G.; Yee, D. Diabetes and Cancer: A Consensus Report. CA Cancer J Clin. 2010, 60, 207222, https://doi.org/10.3322/caac.20078.

6. Pollak, M. The insulin and insulin-like growth factor receptor family in neoplasia: an update. Nature reviews/Cancer. 2012, 12, 159-169. https://doi.org/10.1038/nrc3215.

7. Friedenreich, C.M.; Ryder-Burbidge, C.; McNeil, J.; Friedenreich, C.M. Physical activity, obesity and sedentary behavior in cancer etiology: epidemiologic evidence and biologic mechanisms. Mol Oncol. 2021, 15, 790-800, https://doi.org/10.1002/1878-0261.12772.

8. Currie, C.J.; Poole, C.D.; Gale, E.A. The influence of glucose-lowering therapies on cancer risk in type 2 diabetes. Diabetologia. 2009, 52, 1766-1777, https://doi.org/10.1007/s00125-009-1440-6.

9. Hemkens, L.G.; Grouven, U.; Bender, R.; Günster, C.; Gustschmidt, S.; Selke, G.W. et al. Risk of malignancies in patients with diabetes treated with human insulin or insulin analogues: a cohort study. Diabetologia. 2009, 52, 1732-1744, https://doi.org/10.1007/s00125-009-1418-4.

10. Gentile, M.; Morabito, F.; Martino, M.; Vigna, E.; Martino, E.A.; Mendicino, F.; Martinelli, G.; Cerchione, C. Chemotherapy-based regimens in multiple myeloma I 2020. Panminerva Medica. 2021, 63, 7-12, https://doi.org/10.23736/S0031-0808.20.04145-2. 
11. Dimopoulos, M.A.; Leleu, X.; Moreau, P.; Richardson, P.G.; Liberati, A.M.; Harrison, S.J.; Miles Prince H; Ocio E.M.; Assadourian S.; Campana F.; Malinge L.; Sémiond D.; van de Velde, H.; Yong, K. Isatuximab plus pomalidomide and dexamethasone in relapsed/refractory multiple myeloma patients with renal impairment: ICARIA-MM subgroup analysis. Leukemia. 2021, 35, 562-572, https://doi.org/10.1038/s41375020-0868-z.

12. Chong, L.L.; Soon, Y.Y.; Soekojo, C.Y.; Ooi, M.; Chng, W.J.; de Mel, S. Daratumumab-based induction therapy for multiple myeloma: A systematic review and meta-analysis. Crit. Rev. Oncol. Hematol. 2021, 159, 103211, https://doi.org/10.1016/j.critrevonc.2020.103211.

13. Mikkilineni, L.; Kochenderfer, J.N. CAR T cell therapies for patients with multiple myeloma. Nat Rev Clin Oncol. 2021, 18, 71-84, https://doi.org/10.1038/s41571-020-0427-6.

14. Richardson, P.G.; Oriol, A.; Larocca, A.; Bladé, J.; Cavo, M.; Rodriguez-Otero, P.; Leleu, X.; Nadeem, O.; Hiemenz, J.W.; Hassoun, H.; Touzeau, C.; Alegre, A.; Paner, A.; Maisel, C.; Mazumder, A.; Raptis, A.; Moreb, J.S.; Anderson, K.C.; Laubach, J.P.; Thuresson, S.; Thuresson, M.; Byrne, C.; Harmenberg, J.; Bakker, N.A.; Mateos, M.V.; HORIZON (OP-106) Investigators. Melflufen and Dexamethasone in Heavily Pretreated Relapsed and Refractory Multiple Myeloma. J Clin Oncol. 2021, 39, 757-767, https://doi.org/10.1200/JCO.20.02259.

15. Akentieva, N.P., Shushanov, S.S., Gizatullin, A.R., Prikhodchenco, T.R., Shkondina, N.I., D'Agaro, E. The effect of plant extracts Kalanchoe daigremontiana and Aloe arborescens on the metabolism of human multiple myeloma cells. Biointerface Research in Applied Chemistry. 2021, 11, 13171-13186, https://doi.org/10.33263/BRIAC115.1317113186.

16. Ragbourne, S.C.; Maghsoodi, N.; Streetly, M.; Crook, M.A. The Association between Metabolic Syndrome and Multiple Myeloma. Acta Haematol. 2021, 144, 24-33, https://doi.org/10.1159/000505992.

17. Streetly, M.; Milner, G.; Kazmi, M.; El-Najjar, I.; Schey, S.; Crook, M.A. Myeloma is associated with features of metabolic syndrome. Clin Lymphoma Myeloma Leuk. 2015, 15, 253-254, https://doi.org/10.1016/j.clml.2015.07.538.

18. Gong, I.Y.; Cheung, M.C.; Read, S.; Na, Y.; Lega, I.C.; Lipscombe, L.L. Association between diabetes and haematological malignancies: a population-based study. Diabetologia. 2021; 64, 540-551, https://doi.org/10.1007/s00125-020-05338-7.

19. Wu, W.; Merriman, K.; Nabaah, A.; Seval, N.; Seval, D.; Lin, H.; et al. The association of diabetes and antidiabetic medications with clinical outcomes in multiple myeloma. British Journal of Cancer. 2014, 111, 628636, https://doi.org/10.1038/bjc.2014.307.

20. Sprynski, A.C.; Hose, D.; Kassambara, A.; Vincent, L.; Jourdan, M.; Rossi, J.F.; Goldschmidt, H.; Klein, B. Insulin is a potent myeloma cell growth factor through insulin/IGF-1 hybrid receptor activation. Leukemia. 2010, 24, 1940-1950, https://doi.org/10.1038/leu.2010.192.

21. Freund, G.G.; Kulas, D.T.; Way, B.A.; Mooney, R. A. Functional insulin and insulin-like growth factor-1 receptors are preferentially expressed in multiple myeloma cell lines as compared to B-lymphoblastoid cell lines. Cancer Res. 1994; 54, 3179-3185.

22. Shushanov, S.S.; Kravtsova, T.A., Chernykh, Yu.B.; Cheikina N.N. Insulin Effects on Survival of Human Multiple Myeloma Cells. Bull Exp Biol Med. 2015, 159, 262-265, https://doi.org/10.1007/s10517-015-29372.

23. Kalitin, N.N; Kostyukova, M.N.; Kakpakova, E.S.; Tupitsyn, N.N. Karamysheva, A.F. Expression of vascular endothelial growth factor receptors VEGFR1 in cultured multiple myeloma cells: correlation with immunophenotype and drug resistance. Bull Exp Biol Med. 2012, 153, 883-886, https://doi.org/10.1007/s10517-012-1850-1.

24. Pellat-Deceunynk, C.; Amiot, M.; Bataille, R.; Riet, I.V.; Camp, B.V.; Omede, P.; Boccadoro, M. Human myeloma cell lines as a tool for studying the biology of multiple myeloma: a reappraisal 18 years after. Blood. 1995, 86, 4001-4002, https://doi.org/10.1182/blood.V86.10.4001.bloodjournal86104001.

25. Straus D.S. Growth-stimulatory actions of insulin in vitro and in vivo. Endocr Rev 1984, 5, 356-369, https://doi.org/10.1210/edrv-5-2-356.

26. Gospodarowicz, D.; Moran, J.S. Stimulation of division of sparse and confluent 3T3 cell populations by a fibroblast growth factor, dexamethasone, and insulin. Proc Natl Acad Sci U S A. 1974, 71, 4584-8. https://doi.org/10.1073/pnas.71.11.4584.

27. Freund, G.G.; Kulas, D.T.; Mooney,R.A. Insulin and IGF-1 increase mitogenesis and glucose metabolism in the multiple myeloma cell line, RPMI-8226. J Immunol 1993; 151, 1811-1820. 
28. Rechler, M.M.; Podskalny, J.M.; Goldfine, I.D.; Wells, C.A. DNA synthesis in human fibroblasts: Stimulation by insulin and by nonsuppressible insulin-like activity (NSILA-S). J Clin Endocrinol Metab. 1974, 39, 512-521, https://doi.org/10.1210/jcem-39-3-512.

29. Holley, R.W.; Kiernan, J.A. Control of the initiation of DNA synthesis in 3T3 cells: serum factors. Proc Natl Acad Sci USA. 1974, 71, 2908-2911. https://doi.org/10.1073/pnas.71.7.2908.

30. Temin, H.M. Studies on carcinogenesis by avian sarcoma viruses. VI. Differential multiplication of uninfected and of converted cells in response to insulin. J Cell Physiol. 1967, 69, 377-384. https://doi.org/10.1002/jcp.1040690314.

31. Gey, G.O.; Thalhimer, W. Observations on the effects of insulin introduced into the medium of tissue cultures. Am Med Assoc. 1924, 82, 1609, https://doi.org/10.1001/jama.1924.26520460003014d.

32. Gong, Y.; Ma, Y.; Sinyuk, M.; Loganathan, S.; Thompson, R.C.; Sarkaria, J.N.; Chen, W.; Lathia, J.D.; Mobley, B.C.; Clark, S.W.; Wang, J. Insulin-mediated signaling promotes proliferation and survival of glioblastoma through Akt activation. Neuro Oncol. 2016; 18, 48-57, https://doi.org/10.1093/neuonc/nov096.

33. Vella, V.; Nicolosi, M.L.; Giuliano, M.; Morrione, A.; Malaguarnera, R. Belfiore, A. Insulin Receptor Isoform A Modulates Metabolic Reprogramming of Breast Cancer Cells in Response to IGF2 and Insulin Stimulation. Cells. 2019, 8, 1017, https://doi.org/10.3390/cells8091017.

34. Qiu, J.; Zheng, Q.; Meng, X. Hyperglycemia and Chemoresistance in Breast Cancer: From Cellular Mechanisms to Treatment Response. Front Oncol. 2021, 1,628359, https://doi.org/10.3389/fonc.2021.628359.

35. Mancarella, C.; Morrione, A.; Scotlandi, K. Novel Regulators of the IGF System in Cancer. Biomolecules. 2021, 11, 273, https://doi.org/10.3390/biom11020273.

36. Vella, V.; De Francesco, E.M.; Lappano, R.; Muoio, M.G.; Manzella, L.; Maggiolini, M.; Belfiore, A. Microenvironmental Determinants of Breast Cancer Metastasis: Focus on the Crucial Interplay Between Estrogen and Insulin/Insulin-Like Growth Factor Signaling. Front Cell Dev Biol. 2020, 8, 608412. https://doi.org/10.3389/fcell.2020.608412.

37. Scalia, P.; Giordano, A.; Williams, S.J. The IGF-II-Insulin Receptor Isoform-A Autocrine Signal in Cancer: Actionable Perspectives. Cancers (Basel). 2020, 12, 366, https://doi.org/10.3390/cancers12020366.

38. Landim, B.C.; de Jesus, M.M.; Bosque, B.P.; Zanon, R.G.; da Silva, C.V.; Góes, R.M.; Ribeiro, D.L. Stimulating effect of palmitate and insulin on cell migration and proliferation in PNT1A and PC3 prostate cells: Counteracting role of metformin. Prostate. 2018, 78, 731-742, https://doi.org/10.1002/pros.23517.

39. Hu, L.; Chen, X.; Qiu, S.; Yang, J.; Liu, H.; Zhang, J.; Zhang, D.; Wang, F. Am J Chin Med. 2020, 48, 10051019, https://doi.org/10.1142/S0192415X20500482.

40. Hopkins, B.D.; Goncalves, M.D.; Cantley, L.C. Insulin-PI3K signalling: an evolutionarily insulated metabolic driver of cancer. Nat Rev Endocrinol. 2020, 16, 276-283, https://doi.org/10.1038/s41574-0200329-9.

41. Guillena, C.; Bartolome, A.; Nevadoa, C.; Benitoa, M. Biphasic effect of insulin on beta cell apoptosis depending on glucose deprivation. FEBS Letters. 2008, 582, 3855-3860, https://doi.org/10.1016/j.febslet.2008.10.020.

42. Rachdaoui, N.; Polo-Parada, L.; Ismail-Beigi, F. Prolonged Exposure to Insulin Inactivates Akt and Erk1/2 and Increases Pancreatic Islet and INS1E b-Cell Apoptosis. Journal of the Endocrine Society. 2019, 3, 6990, https://doi.org/10.1210/js.2018-00140.

43. Xiong, C.J.; Li, P.F.; Song, Y.L.; Xue, L.X.; Jia, Z.Q.; Yao, C.X.; et al. Insulin Induces C2C12 Cell Proliferation and Apoptosis Through Regulation of Cyclin D1 and BAD Expression. Journal of Cellular Biochemistry. 2013, 114, 2708-2717, https://doi.org/10.1002/jcb.24619.

44. Zhao, T.; Bai, J.; Zou Q.; Chen, F.; Xie, Y. Insulin in combination with cisplatin induces the apoptosis of ovarian cancer cells via p53 and JNK activation. Molecular Medicine Reports. 2017, 16, 9095-9101, https://doi.org/10.3892/mmr.2017.7752.

45. Porras, A.; Zuluaga, S.; Valladares, A.; Alvarez, A.M.; Herrera, B.; Fabregat, I. Long-Term Treatment with Insulin Induces Apoptosis in Brown Adipocytes: Role of Oxidative Stress. Endocrinology. 2003, 144, 53905401, https://doi.org/10.1210/en.2003-0622.

46. Bucris, E.; Beck, A.; Boura-Halfon, S.; Isaac, R.; Vinik, Y.; Rosenzweig, T.; Sampson, S.R.; Zick, Y. Prolonged insulin treatment sensitizes apoptosis pathways in pancreatic $\beta$ cells. J Endocrinol. 2016, 30, 291307, https://doi.org/10.1530/JOE-15-0505.

47. Li, Z.; Guo, D.; Yin, X.; Ding, S.; Shen, M.; Zhang, R.; Wang, Y.; Xu, R. Zinc oxide nanoparticles induce human multiple myeloma cell death via reactive oxygen species and Cyt-C/Apaf-1/Caspase-9/Caspase-3 
signaling pathway in vitro. Biomed Pharmacother. $\quad 2020, \quad 122, \quad 109712$, https://doi.org/10.1016/j.biopha.2019.109712.

48. Qin, W.; Liu, Q.; Xu, X,; Liu, A.; Zhang, H.; Gu, J.; Zhang, T. A novel Twist1/hsa-miR138-5p/caspase-3 pathway regulates cell proliferation and apoptosis of human multiple myeloma. Ann Hematol. 2020, 100, 1815-1824, https://doi.org/10.1007/s00277-020-04059-6.

49. Kumar, S.K.; Harrison, S.J.; Cavo, M.; de la Rubia, J.; Popat, R.; Gasparetto, C.; Hungria, V.; Salwender, H.; Suzuki, K.; Kim, I.; Punnoose, E.A.; Hong, W.J.; Freise, K.J.; Yang, X.; Sood, A.; Jalaluddin, M.; Ross, J.A.; Ward, J.E.; Maciag, P.C.; Moreau, P. Venetoclax or placebo in combination with bortezomib and dexamethasone in patients with relapsed or refractory multiple myeloma (BELLINI): a randomised, doubleblind, multicentre, phase 3 trial. Lancet Oncol. 2020; 21, 1630-1642, https://doi.org/10.1016/S14702045(20)30525-8.

50. Kaufman, J.L.; Gasparetto, C.; Schjesvold, F.H.; Moreau, P.; Touzeau, C.; Facon, T.; Boise, L.H.; Jiang, Y.; Yang, X.; Dunbar, F.; Vishwamitra, D.; Unger, S.; Macartney, T.; Pesko, J.; Yu, Y.; Salem, A.H.; Ross, J.A.; Hong, W.J.; Maciag, P.C.; Pauff, J.M.; Kumar, S.; Targeting BCL-2 with venetoclax and dexamethasone in patients with relapsed/refractory $\mathrm{t}(11 ; 14)$ multiple myeloma. Am J Hematol. 2021, 96, 418-427, https://doi.org/10.1002/ajh.26083.

51. Wang, Y.; Li, W.; Huang, F.; Wu, X.; Chen, W.; Dong, M.; Zhou, J. Synthesis of sophocarpine triflorohydrazone and its proliferation inhibition and apoptosis induction activity in myeloma cells through Notch3-p53 signaling activation. Environ Toxicol. 2021; 36, 484-490, https://doi.org/10.1002/tox.23053.

52. Cosialls, A.M.; Sánchez-Vera, I.; Pomares, H.; Perramon-Andújar, J.; Sanchez-Esteban, S.; Palmeri, C.M; Iglesias-Serret, D.; Saura-Esteller, J.; Núñez-Vázquez, S.; Lavilla, R.; González-Barca, E.M.; Pons, G.; Gil, J. The BCL-2 family members NOXA and BIM mediate fluorizoline-induced apoptosis in multiple myeloma cells. Biochem Pharmacol. 2020, 180, 114198, https://doi.org/10.1016/j.bcp.2020.114198.

53. Focke, P.J.; Swetlik, A.R.; Schil, J.L and Epstein, M.L. GDNF and insulin cooperate to enhance the proliferation and differentiation of enteric crest-derived cells. J Neurobiol. 2003, 55, 151-164, https://doi.org/10.1002/neu.10204.

54. Campos, S.P.; Wang, Y.; Koj, A.; Baumann, H. Insulin cooperates with IL-1 in regulating expression of $\alpha_{1^{-}}$ acid glycoprotein gene in rat hepatoma cells. Cytokine. 1994, 6, 485-492, https://doi.org/10.1016/10434666(94)90075-2.

55. Rochat, A.; Fernandez, A.; Vandromme, M.; Mole, Jn-P.; Bouschet, T.; Carnac, G. and Lamb, N.J.C. Insulin and Wnt1 Pathways Cooperate to Induce Reserve Cell Activation in Differentiation and Myotube Hypertrophy. Mol.Biol.Cell. 2004, 15, 4544-4555, https://doi.org/10.1091/mbc.e03-11-0816.

56. Toda, G.; Soeda, K.; Okazaki, Y.; Kobayashi, N.; Masuda, Y.; Arakawa, N.; Suwanai, H.; Masamoto, Y.; Izumida, Y.; Kamei, N.; Sasako, T.; Suzuki, R.; Kubota, T.; Kubota, N.; Kurokawa, M.; Tobe, K.; Noda, T.; Honda, K.; Accili, D.; Yamauchi, T.; Kadowaki, T.; Ueki, K. Insulin- and Lipopolysaccharide-Mediated Signaling in Adipose Tissue Macrophages Regulates Postprandial Glycemia through Akt-mTOR Activation. Mol Cell. 2020, 79, 43-53.e4, https://doi.org/10.1016/j.molcel.2020.04.033.

57. Zhu, L.; Du, W.; Liu, Y.; Cheng, M.; Wang, X.; Zhang, C.; Lv, X.; Li, F.; Zhao, S.; Hao, J. Schwann cells apoptosis is induced by high glucose in diabetic peripheral neuropathy. J Cell Biochem. 2019, 120, 57775789, https://doi.org/10.1002/jcb.27864.

58. Stefano, G.B.; Challenger, S.; Kream, R.M. Hyperglycemia-associated alterations in cellular signaling and dysregulated mitochondrial bioenergetics in human metabolic disorders. Eur J Nutr . 2016, 55, 2339-2345, https://doi.org/10.1007/s00394-016-1212-2.

59. Luo, W.; Ai, L.; Wang, B.F.; Zhou, Y.; High glucose inhibits myogenesis and induces insulin resistance by down-regulating AKT signaling. Biomed Pharmacother. 2019, 120, 109498, https://doi.org/10.1016/j.biopha.2019.109498.

60. Devanathan, N.; Jones, S.; Kaur, G.; Kimble-Hill, A.C. Using Phosphatidylinositol Phosphorylation as Markers for Hyperglycemic Related Breast Cancer. Int J Mol Sci. 2020, 21, 2320, https://doi.org/10.3390/ijms21072320.

61. Qian, X.; He, L.; Hao, M.; Li,Y.; Li, X.; Liu, Y.; Jiang, H.; Xu, L.; Li, C.; Wu. W.; Du, L.; Yin, X, Lu.; Q. YAP mediates the interaction between the Hippo and PI3K/Akt pathways in mesangial cell proliferation in diabetic nephropathy. Acta Diabetol. 2021, 58, 47-62, https://doi.org/10.1007/s00592-020-01582-w. 